\title{
Public Policy through Private Law Introduction to a debate on European Regulatory Private Law ${ }^{1}$
}

\author{
Guido Comparato²
}

At the onset of Europeanisation, the discussion on private law followed two main paths. The first one was initially carved by a comparative law exercise devoted to studying how different European legal systems resolved analogous social problems, so as to demonstrate the existence of value convergence and of a common core of general contract law in Europe. ${ }^{3}$ The second path was forged by legal scholars analysing the positive law produced by the European Union with the most direct impact on national private law systems. ${ }^{4}$ When the European Union project was seen to be at the height of both its success and its ambition, these two paths were merged to explore the possibility of codifying a common set of rules on contract law, ${ }^{5}$ leading to another academic exercise, which received political attention.

More recently, following the definitive shelving of European codification projects and given the challenges to EU integration posed by the financial and political crisis (of which the Brexit referendum is a most notable outcome), European legal scholarship has grown increasingly sceptical towards the structure of the EU and critical of its failed aspiration to cosmopolitanism. ${ }^{6}$ In this disenchanted context, an innovative project for the study of European private law has taken off in Florence. Directed by Hans Micklitz and titled 'European Regulatory Private Law' (ERPL), this project steps away from traditional accounts of private law at

\footnotetext{
1 The ERPL project has received funding from the European Research Council under the European Union's Seventh Framework Programme (FP/2007-2013)/ERC Grant Agreement n. 269722. I would like to thank Hans Micklitz and Yane Svetiev for their valuable comments.

${ }^{2}$ Research Associate, European University Institute, Florence, Italy

${ }^{3}$ See the numerous publications stemming from the Common Core of European Private Law project initiated in Trento; among many: M. Bussani and U. Mattei (eds.), The Common Core of European Contract Law. Essays on the Project (The Hague: Kluwer Law International, 2002).

${ }^{4}$ This has mostly interested the area of EU consumer law. See e.g. H. Schulte-Nölke, C. Twigg-Flesner and M. Ebers (eds.), EC Consumer Law Compendium. The Consumer Acquis and its transposition in the Member States (Sellier, 2008).

${ }^{5}$ The academic debate on the Draft Common Frame of Reference has generated a vast amount of literature. See among others H. Eidenmüller, F. Faust, H.C. Grigoleit, N. Jansen, G. Wagner and R. Zimmermann, 'The Common Frame of Reference for European Private Law. Policy Choices and Codification Problems', (2008) 28 Oxford Journal of Legal Studies, 659-708; A. Somma (ed.), The Politics of the Draft Common Frame of Ref- erence (Wolters Kluwer, 2009); P. Larouche and F. Chirico (eds.), Economic Analysis of the DCFR (Sellier, 2010); V. Sagaert, M. Storme and E. Terryn (eds.), The Draft Common Frame of Reference: National and Com- parative Perspectives (Intersentia, 2012).

${ }^{6}$ See notably A. Somek, ‘Europe: Political, Not Cosmopolitan’, (2014) 20 European Law Journal, 142-163. For a discussion of that context, see also Y. Svetiev, 'Regulation or Competition? European Regulatory Private Law as a Platform for Transnational Market-Making', in this issue.
} 
both national and EU level. It focuses, instead, on the regulation of economic activities that, despite their commercial importance, have often been neglected by scholars because of the centrality of consumer law and general contract law themes in European private law discourse. ${ }^{7}$ While the archetype on which the traditional account of general contract law is based is the sales contract, the ERPL project has looked at services, by now the most significant activity in the European economy, including sectors such as energy, telecommunications, transport, finance, health and tourism. These are the sectors that have been most affected over the years by processes of liberalisation and privatisation (not only in the EU). In this context, the role of contract law has gained importance, as public law provisions have charged private law with further goals and objectives. ${ }^{8}$ Such sectors are characterised by a dynamic development of a private law on sectorial terms with a strong regulatory flavour under the influence of EU law. As a result, private law is now an instrument to achieve further public policy objectives at either EU or national level. This feature of EU private law had already been detected with respect to the internal market goal ${ }^{9}$ but has now taken much larger proportions. The ERPL project identifies in this development a remarkable transformation of private law from autonomy to regulation.

Both the traditional conception of private law and the way in which European private law has typically been studied do not adequately take into account—and may even obscure-this transformation. The traditional approach looks at private law as an autonomy-based system rooted in the idea of commutative justice and aimed to provide normatively constructed equal individuals with the means to best pursue their private interest. Such an understanding of private law allows for intrusion into private agreements only for narrowly construed reasons of public interest, which overtime may include social policy considerations. This approach does not exclude that private law might be functionally relevant to shape interpersonal relations according to a certain ideal but downplays its capacity to be employed as an instrument to pursue further-reaching public goals. By contrast, in the ERPL perspective, private law is not characterised as either fully rooted in autonomy or fully socially oriented. New and evolving goals appear relevant to ERPL, ranging from ensuring fairness in transactions, to promoting competition and to the establishment of the internal market (or the new variant of the digital single market). A different conceptualisation seems therefore necessary to make sense of the strongly instrumental character of private law and of newly introduced limitations on freedom of contract, which can paradoxically expand contractual autonomy in the internal market.

\footnotetext{
${ }^{7}$ H.-W. Micklitz, 'The visible hand of European regulatory Private Law. The transformation of European pri- vate law from autonomy to functionalism in competition and regulation', (2009) 28 Yearbook of European Law, 3-59. See also M.W. Hesselink, 'Private Law, Regulation and Justice', in this issue.

${ }^{8}$ On the transformations of private law, see H.-W. Micklitz and Y. Svetiev, 'The transformation(s) of private law', in H.-W. Micklitz, Y. Svetiev and G. Comparato (eds.), 'European Regulatory Private Law. The Paradigms Tested', (2014) 4 EUI Working Papers.

${ }^{9}$ C.U. Schmid, Die Instrumentalisierung des Privatrechts durch die Europäische Union (Nomos, 2010).
} 
The Florence project requires as well a different conceptualisation of the sources of private law. The traditional account of private law sources, based on a clear distinction between adjudication and legislation and often centred on the idea of a systematic code, or at least on the overall coherence of the system, fails to explain how ERPL is actually generated. The Florence project reveals that each sector of ERPL is characterised by a specific institutional design and involves a plurality of non-standard actors and procedures in lawmaking and dispute resolution. The project highlights, as well, that such

EU-triggered private law has been partly displacing national private legal orders.

But what are the normative values enshrined in this law, if any, and the policy goals that its instrumentalist nature promotes? The epoch of increasingly detailed consumer law directives, simply aimed at pursuing harmonisation as if it were a goal in itself, is now over.

The disenchantment of recent years has required higher care and accuracy in identifying appropriate goals for new EU rules. EU legislation has always placed much emphasis on the need to establish an internal market characterised by competition between participants. As a matter of fact, however, the aim to establish the internal market can legitimise very diverse interventions inspired by different principles, and indeed new goals have emerged overtime. Various sectors have developed sub-principles of their own that have eventually gained momentum, such as the goal of stability in the financial sector. In this context, competition no longer seems to be the only or preponderant objective in various economic and industry-specific contexts.

Such findings, emerging from empirical research in the ERPL project, lead to at least two broader questions. First, how does ERPL interact with the traditional view of private law and of national legal orders more generally? Second, how do the private laws and principles of each economic sector interact with each other? The answer to these questions depends, in part, on the values enshrined in each of the considered legal regimes. As to the first question, different modes of interaction of ERLP with domestic laws can be observed at work in different instances: intrusion and substitution, convergence, area hybridisation or conflict and resistance. ${ }^{10}$

On the second question, a focus on the rationality encoded in the rules and procedures of different sectors can make it difficult to identify any overarching principles of the private law system. ERPL shows a tendency towards sectorialisation, which may reflect the empirical reality of the economy, while theoretically challenging the legal system itself and replacing it with several smaller sub-systems of economic law in a process of continuous fragmentation. Each sector is largely closed and separated from the others and the

\footnotetext{
${ }^{10}$ H.-W. Micklitz and Y. Svetiev (eds.), 'A Self-Sufficient European Private Law - A Viable Concept?', (2012) 31 EUI Working Papers. 83-88
} 
communication of rules and principles between such silos does not occur straightforwardly: the problems faced in the telecommunication sector may be different from those in energy or financial services. If this were true, would it be possible to speak of an ERPL order that encompasses all those areas? If not, we would have to acknowledge that private law has lost the capacity to order society, leaving us with a description of disparate tendencies emerging in the economy coupled with dissimilar legal/regulatory approaches tentatively developed to cope with them. Yet despite such fragmentation, some common features may be identified, so that this form of private law describes late modernity rather than post-modernity: legal rules take different forms and are often changed through institutional arrangements favouring experimentalism rather than the settling of stable solutions. Such rules and procedures are nonetheless still meant to achieve identifiable public policy objectives in a given market society. ERPL does therefore display common features among the studied sectors including, in particular, the concepts of regulated autonomy and of access justice.

The notion of regulated autonomy conceptualises the strongly instrumental character of private law, which both restricts and extends private autonomy with a view to achieving different policy objectives within the internal market. ${ }^{11}$ This notion does not refer exclusively to the previously mentioned economic sectors or solely to the EU level of legislation, as autonomy is usually regulated also in national settings. It stands nonetheless in contrast to widespread characterisations of general private law (at the national level but possibly also at the EU level in various academic projects) that idealise private autonomy as an almost natural state of affairs, relatively indifferent, if not opposed, to the regulatory environment.

The concept of access justice, in turn, refers to the way in which sectorial private law aims to promote access to various economic sectors. ${ }^{12}$ Examples include third party access to infrastructure, or to information, or the right of customers to have access to energy or even be 'financially included'. The idea of access is also enshrined in Article 36 of the Chapter of Fundamental Rights that 'recognises and respects' access to services of general economic interest. While the dichotomy between commutative and distributive justice has been the focus of much theoretical discussion in European private law, ERPL focuses on a different concept of justice, which has a less illustrious philosophical tradition but nonetheless emerges from the empirical reality of EU law.

These novel conceptions of autonomy and justice deployed by ERPL can be subject to criticism from different perspectives, prompting a debate far beyond the sectors initially researched in the project. On the one hand, the notion of regulated

\footnotetext{
${ }^{11}$ G. Comparato and H.-W. Micklitz, 'Regulated Autonomy between Market Freedoms and Fundamental Rights in the Case Law of the CJEU', in U. Bernitz, X. Groussot, F. Schulyok (eds.), General Principles of EU Law and European Private Law (Wolters Kluwer, 2013), at 121.

${ }^{12}$ H.-W. Micklitz, 'Social Justice and Access Justice in Private Law’, (2011) 2 European Law Working Papers.
} 
autonomy could turn private autonomy into a regulatory device, further challenging the distinction between private and public law and sacrificing individual choices and relationships at the altar of public policies. ${ }^{13}$ On the other hand, the notion of access justice might prove insensitive to questions of substantive justice and ill equipped to solve conflicts between competing access claims. ${ }^{14}$ The answer to such questions depends in part on the complex interaction between ERPL and private law more generally. If the former embodies a notion of access justice and the latter a notion of commutative/distributive justice, does access justice supplant other ideas of justice? Would the notions hybridise or coexist and complement each other at different levels - for instance the EU and the national one-or would they irremediably conflict? At any rate, the relation between the concepts is intricate, and the reactions of several scholars to such cases as Viking ${ }^{15}$ and Laval ${ }^{16}$ show how confrontational the relationship between social justice and access to the (in those cases, labour) market can be. The problem is magnified when those notions come to be associated with different geopolitical realities relating to the dichotomy between old and new member states. ${ }^{17}$

For the given reasons, an examination of the rules and procedures adopted in specific economic areas prompts a series of considerations that are not only relevant to the sectors in which they originate but also quite scalable and far reaching. Accordingly, this special Issue deals first with the theme of private law's transformation through competition (Micklitz) and regulation (Svetiev). It then addresses some of the theoretical questions that these developments raise, namely the possible departure of the ERPL approach from private autonomy (Dagan) and from other conceptions of justice and legitimacy (Hesselink). The first two articles, written by scholars actively involved in the study of ERPL, present in detail the processes that have been sketched out in this introduction, while the other two contributions are written by scholars external to the project and deeply interested in the theory of private law, who critically assess some of the key underpinnings of ERPL.

As ERPL assumes a transformation from a private law rooted in autonomy to one oriented towards regulation and competition, Hans Micklitz, the initiator of the ERPL idea, looks closely into the concept of competition and its relevance for European private law. As the promotion of competition is one key objective of the $\mathrm{EU}$, the private law that is created at the EU level may be functional to accomplishing that objective, making it possible to speak of a competitive contract law. ${ }^{18}$ While the role of competition in the EU 'economic constitution'

\footnotetext{
${ }^{13}$ See H. Dagan, 'Between Regulatory and Autonomy-Based Private Law', in this issue.

${ }^{14}$ See M.W. Hesselink, 'Private Law, Regulation and Justice', in this issue.

${ }^{15}$ CJEU, C-438/05, Viking.

${ }^{16}$ CJEU, C-341/05, Laval.

${ }^{17}$ See D. Kukovec, 'Law and the Periphery', (2015) 3 European Law Journal, 406-428.

${ }^{18}$ H.-W. Micklitz, 'The Concept of Competitive Contract Law', (2005) 23 Penn State International Law Review, 549-586.
} 
reflects the ordoliberal heritage of the treaties, competitive contract law does not entirely fit into an ordoliberal description of the EU legal system.

Rather than simply trumping private autonomy whenever it would lead to the creation of cartels or monopolies, competition plays a more profound role in private law, turning it into an instrument to achieve competitive markets. The picture is further complicated by the evolution of the very idea of competition, which has come to mean different things over the course of evolution of EU private law. For some part of the history of the EU, competition was promoted not only among market participants but-Micklitz argues — even among legal orders within the EU. Yet in various sectors, competition does not appear to be the only goal pursued. In the case of the banking union, for instance, the importance of competition has been outweighed by the new goal of financial stability, so that competition may be considered as 'suspended'. ${ }^{19}$ Svetiev $^{20}$ then demonstrates that in other sectors, such as electronic communications, and for problems such as roaming, the EU legislator explicitly acknowledges the limits of competition for the purposes of both completing the internal market and delivering favourable market outcomes.

Competition appears thus to be only one of the many policy objectives taken into account by regulatory private law and to be more flexibly addressed through an experimentalist institutional design characterised by a 'problem-solving' approach. If competition law and competitive contract law are not the exclusive instruments to produce desiredcoutcomes, a renewed attention to the regulation of contracts and their regulatory potential emerges. For instance, as Svetiev observes, the CJEU has accepted stronger forms of price regulation at the national level, subject to an experimentalist understanding of proportionality and subsidiarity, to further a variety of public policy goals, including the general goal of contractual fairness.

If ERPL gradually departs from private autonomy-in itself an elusive concept that has undergone deep transformations because of various societal and economic pressures - and aims at achieving a range of public policy goals, what is then the destiny of private law itself? Private law vitally relies on the autonomy of free and equal agents and governs their interpersonal relations, as opposed to their interaction with State authorities. The importance of private law as distinct from public law has been at the centre of a renewed debate in the US context, ${ }^{21}$ after the success of critical theories that de facto debunked the private/public distinction. The topic is discussed by Hanoch Dagan, who provides a constructive criticism of the notion of regulated autonomy. He offers an intermediate view-

\footnotetext{
${ }^{19}$ H.-W. Micklitz, 'The Transformation of Private Law through Competition', in this issue.

${ }^{20}$ Y. Svetiev, 'Regulation or Competition? European Regulatory Private Law as a Platform for Transnational Market-Making', in this issue.

${ }^{21}$ J.C.P. Goldberg, 'Introduction: Pragmatism and Private Law’, (2012) 125 Harvard Law Review, 16401652.
} 
based on liberal philosophers such as Rawls - that recognises the embeddedness of autonomy in social praxis while rejecting the possible equalisation of the public and private spheres. The guiding principle of his analysis is that private law enhances our autonomy rather than safeguarding our independence (as a marketlibertarian private law would assume). Given that premise, Dagan spots a degree of ambivalence in the notion of regulated autonomy, of which he distinguishes two varieties, accepting one and rejecting the other. More specifically, in Dagan's view, regulated autonomy remains loyal to the commitment of private law to enhance autonomy where it 'extends' freedom (including the freedom to involve others in our projects), while it is contrary to relational justice whenever it becomes a regulatory tool itself to achieve further goals. The reader will notice that Dagan's theoretical quest for a normative idea of interpersonal justice does not always match the positive findings illustrated by the contributions by Micklitz and Svetiev and applies imperfectly to a landscape populated not just by individuals but also by corporate entities. Any mismatch between the practices to be found in ERPL and the theoretical account proposed by Dagan on the basis of the idea of a liberal (or Rawlsian) private law leads us ineluctably to questions of justice.

Such questions are taken up in the contribution of Martijn Hesselink. While Dagan

focuses on the concept of regulated autonomy, Hesselink focuses on the second conceptual building block of ERPL, the idea of access justice. The author disagrees first with the proposition that (descriptively) ERPL can account for the 'full picture' of European private law and, second, with the idea that (normatively) access justice can be considered an adequate model of justice for European private law. First, Hesselink suggests that common features other than access justice are extremely well developed in other parts of European private law and in particular in EU consumer law. Second, he focuses on the issue of legitimacy and argues that ERPL might become 'apologetic or even supportive of practices that from a legitimacy point of view, and therefore from the perspective of justice', are 'highly problematic'.22

Despite such complex questions as to the actual — and ever-evolvinginstitutional design of EU law, the empirical reality described in ERPL already offers a lively and stimulating image of private law, characterised by the emergence of new objectives, new arrangements and inventive ways to handle both old and new problems. EU legal integration may therefore have the desirable effect of opening new possibilities for private law, rather than constraining it in a one-dimensional (market) straightjacket.

${ }^{22}$ M. W. Hesselink, 'Private Law, Regulation and Justice', in this issue. 